УДК 616.36-089.87-06:616-091]-092.9

\title{
Морфометрична характеристика структурної перебудови м'язової оболонки порожньої кишки при пострезекційній портальній гіпертензії
}

\author{
Л.В. Татарчук, М.С. Гнатюк \\ hnatjuk@tdmu.edu.ua
}

Тернопільський державний медичний університет імені I. Я. Горбачевського, Тернопіль

\section{Реферат}

Вступ. Видалення великих об'ємів паренхіми печінки може супроводжуватися виникненням пострезекційної портальної гіпертензії. Остання призводить до морфологічної перебудови органів басейну ворітної печінкової вени, ураженням їх структур, морфологічними змінами м'язової оболонки, які при ушкоженнях порожньої кишки у названих патологічних умовах досліджені недостатньо.

Мета дослідження. Вивчити морфометричні особливості структурної перебудови м'язової оболонки порожньої кишки при пострезекційній портальній гіпертензії.

Матеріали та методи. Комплексом морфологічних методів досліджена порожня кишка 45 статевозрілих білих щурів-самців, які були розділені на 3 групи: 1 група - 15 інтактних тварин; 2 - 15 щурів, у яких видалено 31,5\% паренхіми печінки; 3 - 15 тварин після резекції 58,1 \% паренхіми печінки. Евтаназію щурів здійснювали кровопусканням в умовах тіопенталового наркозу через 1 місяць від початку експерименту. Із порожньої кишки виготовляли гістологічні мікропрепарати. Вимірювали товщини колового та поздовжнього шарів м'язової оболонки, діаметр гладких міоцитів та їх ядер, ядерно-цитоплазматичні відношення у цих клітинах, стромально-міоцитарні відношення, відносні об'єми пошкоджених міоцитів.

Результати досліджень та їх обговорення. Встановлено, що через місяць після резекції 31,5 \% паренхіми печінки досліджувані морфометричні показники змінювалися незначно. Видалення 58,1 \% паренхіми печінки призводило до розвитку пострезекційної портальної гіпертензії. Виражено зміненими при цьому виявилися морфометричні параметри структур колового та поздовжнього шарів м'язової оболонки порожньої кишки. Товщина колового шару м'язової оболонки через місяць після резекції 58,1 \% паренхіми печінки статистично достовірно зменшилася на 4,1 \%, діаметр міоцитів - на 6,1 \%, ядерно-цитоплазматичні відношення у них зросли на $35,4 \%$, стромальноміоцитарні відношення - на 14,3 \%, відносний об'єм пошкоджених міоцитів - у 14,4 разу. Кількісні морфологічні показники структур поздовжнього шару м'язової оболонки порожньої кишки через місяць після резекції 58,1% паренхіми печінки змінювалися аналогічно, але ступінь їх вираження був меншим порівняно із структурами колового шару. Так, діаметр міоцитів у даних експериментальних умовах виявився зменшеним всього на 1,6 \%, діаметр ядер зріс на 4,6 \% ( $<0,01)$, ядерно-цитоплазматичні відношення - на 15,2 \% ( $<0,001)$, стромально-міоцитарні відношення - на 14,1 \%, відносний об’єм пошкоджених міоцитів - у 8,1 разу.

Висновки. Видалення великих об'ємів паренхіми печінки призводить до пострезекційної портальної гіпертензії та вираженої морфологічної перебудови (ремоделювання) структур колового та поздовжнього шарів м'язової оболонки порожньої кишки, яка характеризується диспропорційними нерівномірними змінами морфометричних параметрів гладких міоцитів, їх ядер, порушеннями ядерно-цитоплазматичних відношень у цих клітинах, атрофією, зростанням стромальних структур та відносних об'ємів пошкоджених міоцитів у м'язовій оболонці, що може ускладнюватися дисфункцією ушкодженого органа.

Ключові слова: пострезекційна портальна гіпертензія, порожня кишка, м’язова оболонка, ре моделювання.

Morphometric characteristic structural reconstruction of jejunum muscle at postresection portal hyperm L.V. Tatarchuk, M.S. Hnatjuk

Ternopil State Medical University by I. Ya. Horbachevsky, Ternopil

\section{Abstract}

Introduction. Liver resection is widely used in modern surgical departments. Resections of large volumes of liver parenchyma are complicated by postresection portal hypertension, which leads to structural and functional changes in the organs of the basin portal hepatic vein. The features of the structural reconstruction of jejunum muscle at postresection portal hypertension have not been adequately investigated.

The aim of the study. Morphometrical methods to study the features of remodeling of the structures of jejunum muscle at postresection portal hypertension.

Materials and methods. The complex of morphological methods examined the jejunum of 45 sexuale mature white male rats, which were divided into 3 groups. The first group consisted of 15 intact animals, second- 15 rats, in which $31.5 \%$ of the liver parenchyma was removed, third-15 animals after resection of 58,1\% of liver parenchyma. Euthanasia of rats was carried out by bloodletting in conditions of thiopental anesthesia 1 month after from the beginning of the experiment. From the jejunum histological preparations were made. The thickness of the circular and longitudinal muscle layers, the diameters of smooth myocytes and their nuclei, the nuclear-cytoplasmic relations in these cells, the stromal-myocytal relations, and the relative volumes of damaged myocytes were measured. Quantitative indicators were processed statistically.

Results and discussion. It was established that one month after resection of $31.5 \%$ of liver parenchyma, morphometric indices were slightly changed. Removal of $58.1 \%$ of liver parenchyma leads to the development of postresection portal hy- 
pertension. The morphometric parameters of the structures of the circular and longitudinal layers of the muscle cover of the jejunum were manifested by altered ones. The thickness of the circular layer of the muscle membrane a month after the resection of $58.1 \%$ of the liver parenchyma statistically significantly decreased by $4,1 \%$, the diameter of myocytes - by $6.1 \%$, the nuclear-cytoplasmic relation of them increased by $35.4 \%$, stromally -miocytal relation - by $14,3 \%$, relative the number of damaged myocytes - by 14.4 times. Quantitative morphological indices of the structures of the longitudinal layer of the jejunum muscle a month after the resection of $58.1 \%$ of the liver parenchyma changed in a similar manner, but the degree of their expression was smaller compared with the structures of the circular layer. Thus, the diameter of myocytes in the given experimental conditions was reduced by only $1,6 \%$, the diameter of the nuclei increased by $4.6 \%(\mathrm{p}<0.01)$, nuclearcytoplasmic relations - by $15.2 \%(\mathrm{p}<0.001)$, stromally -miocytal relations - by $14,1 \%$, relative volume of damaged myocytes-by 8,1 times.

Conclusions. The results of the study suggest that the removal of large volumes of liver parenchyma leads to postresection portal hypertension and pronounced morphological rearrangement (remodeling) of the structures of the circular and longitudinal layers of the jejunum muscle, characterized by disproportional uneven changes in the morphometric parameters of smooth myocytes, their nuclei, violations of nuclear-cytoplazmatic relations in these cells, atrophy, growth of stromal structures and relative volumes of damaged myocytes in the muscle, which may be complicated by the dysfunction of the organ.

Key words: postresection portal hypertension, jejunum, jejunum muscle, remodeling.

Вступ. У хірургічних клініках нерідко виконують резекцію печінки, яка здійснюється при доброякісних і злоякісних пухлинах, метастазах, травмах печінки, внутрішньопечінковому холангіотіазі, альвеолярному ехінококозі, трансплантації печінки [1,2]. Резекція великих об'ємів печінки може призводити до різних ускладнень, зокрема, до портальної пострезекційної гіпертензії, при якій підвищується тиск крові у системі ворітної печінкової вени, печінкових венах, а також у нижній порожнистій вені $[1,3,4]$. Головними клінічними ознаками портальної гіпертензії є розширення і повнокров'я ворітної печінкової вени, брижових вен, варикозне розширення вен стравохода і шлунка, прямокишкових вен, вен передньої черевної стінки, шлунково-кишкові кровотечі, спленомегалія, асцит. Порожня кишка належить до органів, венозний дренаж від якої здійснюється через ворітну печінкову вену, де гемодинамічні розлади ускладнюються різними морфологічними змінами у судинах та структуpax досліджуваного органа. Необхідно вказати, що особливості ремоделювання структур м'язової оболонки частин тонкої кишки при пострезекційній портальній гіпертензії вивчені недостатньо [3].

Мета дослідження: вивчити морфометричні особливості структурної перебудови м'язової оболонки порожньої кишки при пострезекційній портальній гіпертензі.

Матеріали та методи. Дослідження проведені на 45 лабораторних білих статевозрілих щурахсамцях, які розділені на три групи: перша група включала 15 інтактних тварин (контрольна); друга група - 15 щурів після резекції 31,5 \% паренхіми печінки лівої бокової частки - печінки; третя група - 15 тварин після видалення правої і лівої бокових часток печінки (58,1%) [3]. Евтаназію тварин здійснювали кровопусканням в умовах тіопенталнатрієвого наркозу через 1 місяць від початку експерименту. Усі маніпуляції та евтаназію щурів проводили 3 дотриманням основних принципів роботи 3 експериментальними тваринами у відповідності $з$ положенням «Свропейської конвенції про захист хребетних тварин, які викори- стовуються для експериментальних та інших наукових цілей» (Страсбург, 1986 р.), «Загальних етичних принципів експериментів на тваринах», ухвалених першим національним конгресом 3 біоетики (Київ, 2001 р.), а також Закону України «Про захист тварин від жорстокого поводження» (від 21.02.2006) [5], наказу МОНМС України № 249 від 01.03.2012 р. «Порядок проведення науковими установами дослідів, експериментів на тваринах».

Вирізані шматочки із порожньої кишки фіксували в $10 \%$ нейтральному розчині формаліну i після відповідного проведення через етилові спирти зростаючої концентрації заливали у парафінові блоки за загальноприйнятою методикою. Гістологічні зрізи товщиною 5-7 мкм після депарафінізації фарбували гематоксилін-еозином, за ван-Гізон, Маллорі, Вейгертом, толуїдиновим синім [6]. Морфометрично на мікропрепаратах вимірювали товщину колового шару (ТКШ) та поздовжнього шару (ТПШ) м'язової оболонки порожньої кишки, діаметр гладких міоцитів вказаних шарів (ДМК, ДМП), діаметри їх ядер (ДЯК, ДЯП), визначали ядерно-цитоплазматичні відношення (ЯЦВК, ЯЦВП) у досліджуваних клітинах, стромально-міоцитарні відношення у названих шарах м'язової оболонки (СМВК, СМВП), відносні об'єми пошкоджених міоцитів у них (ВОПМК, ВОПМП [7]. Морфометрію вказаних структур проводили за допомогою світлового мікроскопа «Olimpus BX-2» 3 цифровою відеокамерою і пакетом прикладних програм «Відео Тест 5,0» та «Відео розмір 5,0». Кількісні величини оброблялися статистично. Обробка результатів виконана у відділі системних статистичних досліджень Тернопільського державного медичного університету імені I. Я. Горбачевського в програмному пакеті Statsoft STATISTIKA. Різницю між порівнювальними величинами визначали за критеріями МаннаУітні та Стьюдента [8].

Результати досліджень та їх обговорення. Отримані морфометричні параметри структур м'язової оболонки порожньої кишки дослідних тварин представлені в таблиці 1. При аналізі наведених у таблиці 1 даних встановлено, що товщина 
колового шару м'язової оболонки непошкодженої порожньої кишки з вираженою статистичною достовірністю $(\mathrm{p}<0,001)$ у 1,4 разу перевищувала аналогічний морфометричний показник поздовжнього шару. Неоднаковим при цьому виявився діаметр гладких міоцитів та їх ядер у досліджуваних шарах м'язової оболонки порожньої кишки. Більші вказані кількісні морфологічні показники колового шару м'язової оболонки порівняно 3 поздовжнім свідчать, що попередня структура інтенсивніше функціонує та виконує більшу роботу і $є$ більш потужною. Ядерно-цитоплазматичні відношення у гладких міоцитах, стромально-міоцитарні відношення, відносний об'єм пошкоджених міоцитів у досліджуваних шарах м'язової оболонки неушкодженої порожньої кишки підтверджуване наведене вище [3].

Через місяць після резекції 31,5 \% паренхіми печінки морфометричні параметри колового та поздовжнього шарів м'язової оболонки порож- ньої кишки змінювалися незначно. У досліджуваних експериментальних умовах виявлено статистично достовірне $(\mathrm{p}<0,001)$ збільшення відносного об'єму пошкоджених міоцитів у коловому шарі у 1,9 разу, а у поздовжньому у 1,6 разу. Серед пошкоджених міоцитів спостерігалися переважно апоптично змінені клітини, що може бути обумовлено зростанням ї кількості при стресових ситуаціях (оперативні втручання) та віком [9].

У дослідних тварин через місяць після резекції 58,1 \% паренхіми печінки при розтині очеревинної порожнини виявили розширення печінкової ворітної вени, повнокров'я i розширення брижових вен та венозного русла тонкої та товстої кишок, асцит, спленомегалія. Слизова оболонка порожньої кишки повнокровна, набрякла, з поодинокими осередками точкових крововиливів. Описане вище свідчило про наявність пострезекційної портальної гіпертензії [3].

Таблиця 1

Морфометрична характеристика м’язової оболонки порожньої кишки експериментальних тварин (M \pm m)

\begin{tabular}{|l|l|l|l|}
\hline \multirow{2}{*}{ Показник } & \multicolumn{3}{|c|}{ Група спостереження } \\
\cline { 2 - 4 } & перша & \multicolumn{1}{|c|}{ друга } & \multicolumn{1}{c|}{ третя } \\
\hline ТКШ, мкм & $56,65 \pm 0,45$ & $56,40 \pm 0,48$ & $54,30 \pm 0,42^{*}$ \\
\hline ДМК, мкм & $9,05 \pm 0,06$ & $9,10 \pm 0,05$ & $8,50 \pm 0,03 * * *$ \\
\hline ДЯК, мкм & $2,80 \pm 0,02$ & $2,85 \pm 0,03$ & $3,06 \pm 0,02 * * *$ \\
\hline ЯЦВК & $0,096 \pm 0,001$ & $0,098 \pm 0,001$ & $0,130 \pm 0,003^{* * *}$ \\
\hline СМВК & $0,126 \pm 0,002$ & $0,130 \pm 0,003$ & $0,144 \pm 0,002^{* * *}$ \\
\hline ВОПМК \% & $2,26 \pm 0,02$ & $4,30 \pm 0,04 * * *$ & $2,60 \pm 0,36^{* * *}$ \\
\hline ТПШ, мкм & $39,80 \pm 0,33$ & $39,50 \pm 0,42$ & $33,80 \pm 0,36^{* * *}$ \\
\hline ДМП, мкм & $6,12 \pm 0,04$ & $6,14 \pm 0,03$ & $6,02 \pm 0,03 *$ \\
\hline ДЯП, мкм & $2,83 \pm 0,02$ & $2,83 \pm 0,02$ & $2,96 \pm 0,02^{* *}$ \\
\hline ЯЦВП & $0,210 \pm 0,002$ & $0,212 \pm 0,003$ & $0,242 \pm 0,003 * * *$ \\
\hline СМВП & $0,128 \pm 0,001$ & $0,130 \pm 0,002$ & $0,146 \pm 0,002 * * *$ \\
\hline ВОПМП, \% & $2,14 \pm 0,02$ & $3,50 \pm 0,03 * * *$ & $17,30 \pm 0,12^{* * *}$ \\
\hline
\end{tabular}

Примітка: * $-\mathrm{p}<0,05 ; * *-\mathrm{p}<0,01 ; * * *-\mathrm{p}<0,001$, порівняно $з$ першою групою спостережень.

У даних експериментальних умовах виявлено виражене ремоделювання структур м'язової оболонки порожньої кишки, що підтверджувалося змінами іiі морфометричних параметрів. Так, товщина колового шару досліджуваного органа зменшилася $3(56,65 \pm 0,45)$ мкм до $(54,30 \pm 0,42)$ мкм. Наведені кількісні морфологічні показники статистично достовірно $(\mathrm{p}<0,05)$ відрізнялися між собою і останній морфометричний параметр виявився меншим за попередній на 4,1 \%. Діаметр гладких міоцитів даного шару м'язової оболонки порожньої кишки у досліджуваних експериментальних умовах 3 вираженою статистично достовірною різницею ( $<0,001)$ зменшився на $6,1 \%$. Діаметр ядер вказаних клітин збільшився на $6,25 \%(\mathrm{p}<0,001)$. Нерівномірні, диспропорційні зміни просторових характеристик гладких міоцитів та їх ядер у коловому шарі м'язової оболонки порожньої кишки через місяць після видалення
51,8 \% паренхіми печінки призводили до порушень ядерно-цитоплазматичних відношень у названих клітинах. Вказаний морфометричний параметр виявився статистично достовірно $(\mathrm{p}<0,001)$ збільшеним при цьому на 35,4 \%. Виражено зростали у даних експериментальних умовах стромально-міоцитарні відношення та відносний об'єм пошкоджених міоцитів у даному шарі м'язової оболонки порожньої кишки. Вказані морфометричні параметри при цьому відповідно збільшилися на $14,3 \%(\mathrm{p}<0,001)$ та у 14,4 разу $(\mathrm{p}<0,001)$. Варто вказати, що деякі дослідники виражені зміни співвідношень між ядром та цитоплазмою клітин вважають порушенням клітинного, а аналогічні зміни між міоцитами та стромою тканинного структурного гомеостазів $[3,7,10]$.

Кількісні морфологічні показники структур поздовжнього шару м'язової оболонки порожньої кишки через місяць після резекції 58,1% па- 
ренхіми печінки змінювалися аналогічно, але ступінь їх вираження був дещо меншим порівняно зі структурами колового шару. Так, діаметр міоцитів у даних експериментальних умовах виявився зменшеним всього на 1,6 \%, діаметр ядер зріс на 4,6 \% ( $<0,01)$, ядерно-цитоплазматичні відношення - на 15,2\% $(\mathrm{p}<0,001)$, стромально-міоцитарні відношення - на 14,1 \%, відносний об'єм пошкоджених міоцитів - у 8,1 разу.

Світлооптично в оболонках стінки порожньої кишки спостерігалися виражені судинні розлади, набряки строми, осередки дистрофічно, некробіотично, апоптично змінених епітеліоцитів, гладких міоцитів, вогнищеві інфільтрати та розростання сполучної тканини. Відзначався також набряк ендотеліоцитів, їх дистрофія, некробіоз, десквамація та проліферація. Останнє свідчило про наявність гіпоксії. Виражене пошкодження більшості ендотеліоцитів може призводити до ендотеліальної дисфункції та посилювати ушкодження клітин та тканин [11]. Варто також зазначити, що виявлені патогістологічні ушкодження стінки порожньої кишки в умовах пострезекційної портальної гіпертензії корелювали 3 такими морфометричними параметрами, як ядерно-цитоплазматичні відношення у гладких міоцитах, стромально-міоцитарні відношення у м'язовій оболонці органа, відносний об'єм ушкоджених міоцитів. Відомо, що наявне венозне повнокров'я призводить до тканинної гіпоксії, яка сприяє депривації компенсаторних механізмів адаптації та зниженню резистентності клітинних структур до пошкоджуючої дії негативних чинників метаболізму [12]. Морфометричні виміри структур порожньої кишки та отримані результати свідчать, що в умовах пострезекційної портальної гіпертензії у названому органі виникають атрофічні процеси (зменшення розмірів структур, заміна клітин сполучною тканиною), що обумовлено гіпоксією, запальними процесами та імунними реакціями, що мають місце при змодельований патології [13]. Виявлені зміни у м'язовій оболонці можуть призводити до порушення моторики та дисфункції кишки $[3,9,14]$.

На основі отриманих результатів проведеного дослідження та даних літератури можна стверджувати, що видалення великих об'ємів паренхіми печінки призводить до пострезекційної портальної гіпертензії та вираженої структурної перебудови (ремоделювання) колового i поздовжнього шарів м'язової оболонки порожньої кишки, що характеризується нерівномірними диспропорційними змінами просторових характеристик структур органа, порушенням відношень між ними, судинними розладами, набряком, дистрофічними, некробіотичними змінами епітеліоцитів, міоцитів, ендотеліоцитів, стромальних елементів, атрофічними, інфільтративними та склеротичними процесами.

Висновки. Видалення значних об'ємів паренхіми печінки призводить до пострезекційної портальної гіпертензії та вираженого ремоделювання структур колового i поздовжнього шарів м'язової оболонки порожньої кишки, яке характеризується диспропорційними нерівномірними змінами морфометричних параметрів гладких міоцитів, їх ядер, порушеннями ядерно-цитолазматичних відношень у цих клітинах, стромально-міоцитарних відношень, атрофією, зростанням стромальних структур та відносних об'ємів ушкоджених міоцитів у м'язовій оболонці, що може ускладнюватися дисфункцією органа.

Інформація про конфлікт інтересів: відсутній.

Інформація про фінансування: автори гарантують, що вони не отримували жодних винагород у будь-якій формі, здатних вплинути на результат роботи.

Особистий внесок кожного автора у виконанні роботи:

Татарчук Л.В. - провела експеримент та статистичну обробку даних.

Гнатюк М.С. - провів аналіз експериментальних даних і підготував статтю до друку.

\section{Список використаної літератури}

1. Vishnievskii VA, Yefanov MG, Kazakov IV. Segmentarnyye rezektsyi, otdaliennyye rezultaty pri zlokachestvennykh opukholiakh piechieni. Ukraynskyi Zhurnal Khirurgii. 2012; 1 (16): 5-15 [in Ukrainian].

2. Fiodorov VD, Vishnievskiy VA. Nazarienko NA. Osnovnyi oslozhnieniya obshyrnykh rezekcyi pecheni i puti ikh preduprezhdeniya. Biulleten Sibirskoi mieditsyny. 2007; 4:16-24 [in Russian].

3. Shulgai AH, Tatarchuk LV, Hnatjuk MS. Osoblyvostey remodeliuvanja sudyn hemomicrocyrculatornogo rusla klubovoi kyshky pry resekcyy riznych objemiv pechinky. Visnyk naukovyi doslidgen. 2017; 4: 145-9. [in Ukrainian] DOI 10.11603/2415-8798.2017.4.8355.

4. Nanashima A, Sumida Y, Abo T. A modified grading system for posthepatectomy metastatic liver cancer originating form colorectal carcinoma. J. Surg. Oncol. 2008 Jun 12; 98: 363-370.

5. Reznikov OH. Zahalni etychni pryntsypy eksperymentiv na tvarynakh. Endokrynolohiia. 2003; 8, 1: 142- 5 [in Ukrainian].

6. Sorochinnikov AG, Dorosievich AYe. Gistologichieskaya i mikroskopicheskaya tiekhnika. Moskwa: Meditsyna; 2007. 448 s. [in Russian].

7. Avtadnilov GG. Osnovy kolichestvennoy patologicheskoy anatomii. Moskwa: Meditsyna; 2002. 240 s. [in Russian]. 
8. Lapach SN, Gubenko AV, Babich PN. Statistichieskiie metody v medico-biologicheskikh issledovaniyakh Excell. Kyiv: Morion; 2001. 410 s. [in Ukrainian].

9. Mosyychuk LN, Zak My. Khronichnyy hastryt. Novosty medytsyny y farmatsyy. 2010; 21 (349): 12-5 [in Ukrainian].

10. Sarkisov DS. Strukturnyie osnovy adaptatsyi i kompensatsyi narushennykh funktsyi. Moskwa: Meditsyna; 1998. 230 s, [in Russian].

11. Makarov MA, Avdieiev SH, Chuchalin AG. Rol disfunktsyi endoteliia i regidnosti arteriy v patogenezie khronicheskoy obstruktivnoy boliezni liegkikh. Terapevtichieskiy arkhiv. 2012; 3: 74-80 [in Russian].

12. Khukhlina OS, Dudka TV, Shumki HI. Bronkhial'na astma ta khronichni kholetsystyt: osoblyvosti klitinnyy perebihu, mekhanizy vzayemoobtyazhennya, shlyakhy patohennoyi korektsiyi. Chernivtsi: BDMU; 2018.194 s. [in Ukrainian].

13. Kimakovych VY, Chop'yak VV, Brodyk OV. Imunna systema shlunkovo-kyshkovoho traktu v normi ta patolohiyi. Ternopil: Ukrmedknyha; 1999. 100 s. [in Ukrainian].

14. Benedykt VV. Pro znachennya protsesiv enerhozabezpechennya tonkoyi kyshky v patohenezi yiyi funktsional'noyi neprkhidnosti pry poshyrenomu perytoniti i kyshkoviy neprokhidnosti. Shpytal'na khirurhiya. 2010 ; 2 (50): 59-62 [in Ukrainian].

Стаття надійшла до редакції: 5.03.2019 р. 